\title{
Spatial variability in growth and prey availability of lobsters in the northwestern Hawaiian Islands
}

\author{
Joseph M. O'Malley ${ }^{1,4, *}$, Jeffrey C. Drazen², Brian N. Popp ${ }^{3}$, Elizabeth Gier ${ }^{3}$, \\ Robert J. Toonen ${ }^{1}$ \\ ${ }^{1}$ Hawaii Institute of Marine Biology, University of Hawai'i at Mānoa, Kāne'ohe, Hawai'i 96744, USA \\ ${ }^{2}$ Department of Oceanography, University of Hawai'i at Mānoa, Honolulu, Hawai'i 96822, USA \\ ${ }^{3}$ Department of Geology and Geophysics, University of Hawai'i at Mānoa, Honolulu, Hawai'i 96822, USA
}

${ }^{4}$ Present address: Joint Institute for Marine and Atmospheric Research, Research Corporation of the University of Hawai'i, Honolulu, 96822 Hawai'i, USA

\begin{abstract}
Proximate composition, bulk tissue and amino acid compound-specific nitrogen isotopic analyses (CSIA) were used to determine whether dietary differences were responsible for the spatial variability in growth of spiny lobster and slipper lobster in the Northwestern Hawaiian Islands (NWHI). Abdominal tissues were collected and analyzed from both species at Necker Island and Maro Reef from 2006 to 2008. Protein and lipid levels did not differ significantly between locations in either species. Bulk tissue ${ }^{15} \mathrm{~N}$ of both species was significantly negatively correlated with growth for both species; however, the analysis assumed constant isotopic composition of autotrophs across this region. CSIA, which accounts for ${ }^{15} \mathrm{~N}$ variability at the base of the food web, indicated that spiny lobsters at both locations occupied the same trophic position whereas the slower-growing Maro Reef slipper lobsters fed at a lower trophic position relative to Necker Island slipper lobsters. Spatial variability in the abundance or diversity of preferred prey items appears to be responsible for the spatial variability in growth and the specific morphology and behavior of these species dictated how they coped with dietary restraints. These findings increase the understanding of NWHI coral reef ecosystem processes as well as highlight dangers of using consumer bulk tissue isotopic data without considering variation in the nitrogen isotopic composition at the base of the food web.
\end{abstract}

KEY WORDS: Proximate composition · Panulirus marginatus $\cdot$ Scyllarides squammosus $\cdot$ Bulk stable isotope $\cdot$ Compound-specific isotopic analysis $\cdot$ Trophic level

Resale or republication not permitted without written consent of the publisher

\section{INTRODUCTION}

Identifying the drivers of somatic growth variability is important when seeking an understanding of ecosystem dynamics. It becomes essential if the variability adds spatial structure to a species exploited by a fishery striving for effective, sustainable management (Pollock 1991, Rindorf et al. 2008). Without understanding the drivers, growth estimates may be applied erroneously to subsets of a metapopulation, leading to biased yield estimates, inappropriate har- vest levels and the potential of stock collapse. Decapod crustaceans are particularly vulnerable because spatial variability in growth has been demonstrated in nephrop (Fogarty 1995, Wahle \& Fogarty 2006), palinurid (McGarvey et al. 1999, O'Malley 2009) and scyllarid lobsters (O'Malley 2011).

A commercial fishery targeted Hawaiian spiny lobster Panulirus marginatus and scaly slipper lobsters Scyllarides squammosus in the Northwestern Hawaiian Islands (NWHI), a series of islands, reefs, seamounts and atolls (hereafter referred to as banks) 
extending approximately $2000 \mathrm{~km}$ across the subtropical Pacific (Fig. 1). Recaptures from a 2002-2008 mark/recapture study revealed spatial variability in the growth of both NWHI lobster species. Specifically, spiny lobster growth at Necker Island, located at the southeastern end of the NWHI, was approximately one-third that of spiny lobster at Gardner Pinnacles and Maro Reef, located in the middle of the NWHI (O'Malley 2009). During the same time, slipper lobsters, particularly males, grew fastest at Necker Island with growth declining in a northwestern gradient (O'Malley 2011). These results led to a revision of the NHWI lobster population dynamic theory from a single archipelago-wide population to a series of discrete species-specific metapopulations separated by the deep water between banks and connected only by larval dispersal.

Common drivers of crustacean growth were examined to understand the spatial variability in NWHI lobster growth. The first, density dependence (McGarvey et al. 1999, Pollock 1991), was not supported because analysis of individual- and bank-specific growth rates relative to density indicated no relationship for either species (O'Malley 2009, 2011). Temperature, the primary environmental influence on crustacean growth because of its effect on metabolism (Chittleborough 1975, Wahle \& Fogarty 2006, Delestang et al. 2009), did not have an association with annual NWHI spiny lobster growth variability (O'Malley 2009). Spatially separated stocks, some genetically predisposed to slower growth, were also deemed unlikely because spiny lobster pre-

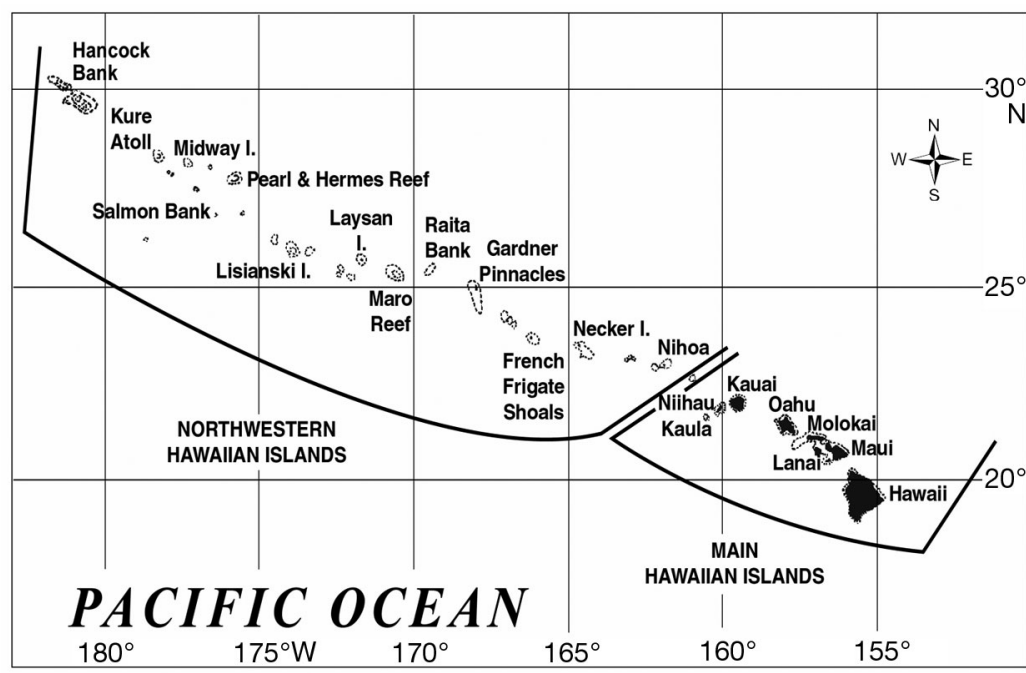

Fig. 1. The Hawaiian Archipelago, including the Northwestern Hawaiian Islands. Study sites are Necker Island, Gardner Pinnacles, Maro Reef and Laysan Island exploitation allozyme frequency analysis found a single panmictic stock throughout the Hawaiian Archipelago (Shaklee \& Samollow 1984) and postexploitation of allozyme frequency analysis in Necker Island and Maro Reef spiny lobster found no differences in 6 out of 7 loci (Seeb et al. 1990). Likewise, a recent survey of 27 taxonomically and ecologically diverse species (including reef fishes, marine mammals, gastropods, echinoderms, cnidarians and crustaceans) revealed multiple shared barriers to dispersal along the length of the Hawaiian Archipelago, but none between Necker Island and Maro Reef (Toonen et al. 2011). Also doubtful is genetic selection for slowergrowing individuals from intense fishing pressure (Conover \& Munch 2002), based on the historically smaller spiny lobsters at Necker Island (Uchida et al. 1980) and the similar levels of exploitation of both species at Necker Island, Gardner Pinnacle and Maro Reef.

Diet also has a large influence on crustacean growth (Conklin 1980, Dall \& Moriarty 1983, Mente 2003). Food availability and quality influenced the spatial growth dynamics of South African rock lobster Jasus lalandii (Mayfield et al. 2000) and Western Australian rock lobster Panulirus cygnus (Edgar 1990). The diet of NWHI lobsters is unknown and, despite recent research efforts in the NWHI (Friedlander et al. 2009), very little is known about the diversity and abundance of potential lobster prey items at any bank. However, opportunistic sampling of abdominal tissue from both lobster species at Necker Island and Maro Reef from 2006 through 2008 enables the use of biochemical techniques to infer that differences in diet may be responsible for the spatial variability in growth.

Nutritional condition can be assessed using proximate composition analysis because lipids are important stores of energy (Chang \& O'Connor 1983, Torres et al. 1994, Drazen 2002) and protein synthesis is required for growth (Claybrook 1983). Within palinurid lobsters, hepatopancreas lipid content showed a positive correlation with growth of Jasus lalandii (Cockcroft 1997) and abdominal tissue and hepatopancreas protein concentrations were significantly lower in starving Panulirus longipes (Dall 1974). Dietary differences can be inferred from the results of bulk tissue stable isotope analysis with carbon isotopic composition $\left({ }^{13} \mathrm{C} /{ }^{12} \mathrm{C}\right)$ identifying the 
source of primary production (DeNiro \& Epstein 1978, Peterson \& Fry 1987) and nitrogen isotopic composition $\left({ }^{15} \mathrm{~N} /{ }^{14} \mathrm{~N}\right)$ revealing trophic dynamics (DeNiro \& Epstein 1981, Minagawa \& Wada 1984). Starvation can also be identified using nitrogen stable isotope analysis because the tissue of starving individuals can be enriched in ${ }^{15} \mathrm{~N}$ relative to healthy individuals due to catabolic processes (Hobson et al. 1993, Adams \& Sterner 2000). However, the $\delta^{15} \mathrm{~N}$ value of a consumer reflects not only its trophic level but also the $\delta^{15} \mathrm{~N}$ value of the primary producers at the base of the food web (e.g. Post 2002, Popp et al. 2007). Therefore, spatial comparisons of bulk isotopic data, particularly trophic position, are compromised without establishing an isotopic baseline at each location (Post 2002, Lorrain et al. 2009).

Two methods are available to quantify isotopic compositions at the base of a food web. The first is to determine the bulk isotopic value of primary producers or primary consumers supporting the predator's food web (Post 2002). However, the $\delta^{15} \mathrm{~N}$ values of marine primary producers can vary significantly spatially and temporally (Cabana \& Rasmussen 1996, Lourey et al. 2003, Popp et al. 2007, Sarà 2007), further complicating the elucidation of trophic relationships. Longerlived primary consumers tend to integrate isotopic variability of the base of the food web (Sarà 2007). However, those species in NWHI lobster food webs are unknown, thus preventing this type of analysis.

The second method is compound-specific nitrogen isotopic analysis (CSIA) of individual amino acids within the tissue of a consumer. Certain amino acids undergo significant enrichment in ${ }^{15} \mathrm{~N}(\sim 7$ to $8 \%$ relative to prey) because of isotopic fractionation that occurs during transamination and deamination reactions (McClelland \& Montoya 2002, Chikaraishi et al. 2007) and are referred to as 'trophic' amino acids (Popp et al. 2007, Hannides et al. 2009). Other amino acids do not undergo these reactions; therefore, they are depleted in ${ }^{15} \mathrm{~N}$ relative to trophic amino acids in consumers and are considered as 'source' amino acids because they are representative of the $\delta^{15} \mathrm{~N}$ values of the primary producers (McClelland \& Montoya 2002, Popp et al. 2007, Chikaraishi et al. 2009). Thus, information about the base of the food web and the trophic level of the consumer can be determined within an individual.

The goal of the present study is to utilize biochemical techniques to infer whether diet is responsible for the spatial variability in growth of NWHI spiny lobster and slipper lobster. The techniques have the ability to reveal nutritional stress (proximate composition), starvation (proximate composition and bulk tissue isotopic analysis) or differences in trophic position that indicate different prey items (bulk tissue isotopic analysis and CSIA). CSIA will also indicate whether spiny lobster and slipper lobster bulk tissue $\delta^{15} \mathrm{~N}$ values are controlled by trophic level or the isotopic composition at the base of the food web.

\section{MATERIALS AND METHODS}

\section{Tissue collection}

Necker Island and Maro Reef spiny lobster and slipper lobster abdominal tissue samples were collected during the 2006-2008 NWHI lobster tag/ recapture cruises (O'Malley 2009, 2011). Lobsters were chosen at random during trapping operations at each bank but individuals within specific carapace lengths (spiny lobster $=72.0-118.0 \mathrm{~mm}$; slipper lobster $=65.0-86.0 \mathrm{~mm}$ ) were selected for analysis to reduce size effects. To avoid the influence of molt stage on biochemical analysis, Lyle \& MacDonald's (1983) protocol was used to ensure that only lobsters in intermolt phase were sampled. Tissue samples were extracted from the dorsal portion of the abdomen and immediately frozen at $-20^{\circ} \mathrm{C}$.

\section{Proximate composition analysis}

Fifteen samples for each species from each bank were prepared for proximate composition analysis. Triplicate lipid and protein assays were performed on 2 samples of each lobster tissue, which were homogenized in distilled water. Lipids were extracted according to Bligh \& Dyer (1959) and total lipids were measured by the charring method of Marsh \& Weinstein (1966). Precision of the lipid assay, expressed as the coefficient of variation, was $6.4 \%$ (range $0.5-22.3 \%$ ) and $5.4 \%$ (range $1.0-16.1 \%$ ) for spiny lobster and slipper lobster, respectively. The bicinchoninic acid protein assay (Smith et al. 1985), with bovine serum albumin as a reference, was used to determine protein content. Precision of the protein assay, expressed as the coefficient of variation, was $2.1 \%$ (range $0.4-5.6 \%$ ) and $2.2 \%$ (range $0.3-5.6 \%$ ) for spiny lobster and slipper lobster, respectively.

\section{Bulk tissue isotope analysis}

Muscle is the most appropriate tissue type for crustacean isotopic analysis and acid treatment is unnec- 
essary if the sample does not contain exoskeleton (Yokoyama et al. 2005). Thirty-six muscle samples for each species from Necker Island and 33 from Maro Reef were prepared for bulk isotopic analysis by oven drying $\left(60^{\circ} \mathrm{C}\right.$ for $\left.72 \mathrm{~h}\right)$ and then grinding to a fine homogeneous powder using a dental amalgamator (HS-1, Henry Schein). Isotopic analysis was performed using an online carbon-nitrogen analyzer coupled with an isotope ratio mass spectrometer (Finnigan ConFlo II/Delta-Plus). Carbon and nitrogen isotopic values are reported in $\delta$ notation (\%o) relative to international standards of Vienna PeeDee Belemnite for $\delta^{13} \mathrm{C}$ values and atmospheric $\mathrm{N}_{2}$ for $\delta^{15} \mathrm{~N}$ values according to:

$$
\delta X_{\text {sample }}=\left[\left(R_{\text {sample }} / R_{\text {reference }}\right)-1\right] \times 1000
$$

where $X$ is ${ }^{13} \mathrm{C}$ or ${ }^{15} \mathrm{~N}$ and $R$ is the corresponding ${ }^{13} \mathrm{C} /{ }^{12} \mathrm{C}$ or ${ }^{15} \mathrm{~N} /{ }^{14} \mathrm{~N}$ ratio. Nitrogen and carbon analytical precisions were $\leq 0.2 \%$, as estimated from glycine standards analyzed with the samples.

\section{Compound-specific isotopic analysis}

Four Necker Island and Maro Reef spiny lobster and slipper lobster samples from 2007 were prepared for CSIA by acid hydrolysis followed by derivation to produce trifluoroacetic amino acid esters using procedures described previously (Popp et al. 2007, Hannides et al. 2009, Dale et al. 2011). Briefly, the samples were hydrolyzed $\left(6 \mathrm{~N} \mathrm{HCl}, 150^{\circ} \mathrm{C}, 70 \mathrm{~min}\right)$ and purified by filtration $(0.2 \mu \mathrm{m})$ and cation-exchange chromatography. Samples were re-acidified prior to the derivatization process that consisted of esterification with subsequent trifluoracetylation (TFA). Samples were further purified by solvent extraction following Ueda et al. (1989) using $2 \mathrm{ml}$ of P-buffer $\left(\mathrm{KH}_{2} \mathrm{PO}_{4}+\right.$ $\mathrm{Na}_{2} \mathrm{HPO}_{4}$ in milli-Q water, $\mathrm{pH}$ 7). Prior to analysis, the TFA derivatives were dried and re-dissolved in ethyl acetate. The nitrogen isotopic composition of TFA derivatives of amino acids were analyzed by isotope ratio monitoring gas chromatography-mass spectrometry using a Finnigan Delta XP mass spectrometer interfaced to a Trace gas chromatograph through a GC-C III combustion furnace $\left(980^{\circ} \mathrm{C}\right)$, a reduction furnace $\left(650^{\circ} \mathrm{C}\right)$ and a liquid nitrogen cold trap. L-2-aminoadipic acid and norleucine, for which the $\delta^{15} \mathrm{~N}$ values had been previously independently determined, were co-injected as internal reference compounds. Each sample was analyzed in triplicate and the $\delta^{15} \mathrm{~N}$ values were corrected relative to the $\delta^{15} \mathrm{~N}$ value of the amino acid internal reference compounds. The mean of the triplicate standard deviations was
$0.5 \%$ (range $0-1.7 \%$ ) for spiny lobsters and $0.4 \%$ (range 0-1.1\%) for slipper lobsters.

The fractional trophic position of lobsters was calculated using the measured $\delta^{15} \mathrm{~N}$ values of glutamic acid and phenylalanine as described by Chikaraishi et al. (2009):

$$
\mathrm{TP}_{\mathrm{Glu} / \mathrm{Phe}}=\frac{\left(\delta^{15} \mathrm{~N}_{\mathrm{Glu}}-\delta^{15} \mathrm{~N}_{\mathrm{Phe}}\right)-3.4}{7.6}+1
$$

where $\mathrm{TP}_{\mathrm{Glu} / \mathrm{Phe}}$ is the trophic position determined using glutamic acid (Glu) and phenylalanine (Phe), 3.4 is the isotopic difference between glutamic acid and phenylalanine in the primary producer $(\beta)$, and 7.6 is the trophic enrichment factor (TEF). A conservative error associated with the trophic position calculation was determined by propagation of error (e.g. Gelwicks \& Hayes 1990) using the uncertainty in $\beta$ and the TEF in Chikaraishi et al. (2009), as well as the measured analytical reproducibility for glutamic acid and phenylalanine for each sample.

\section{Statistical analysis}

Two-sample $t$-tests were used to examine the effect of sex on protein, lipid, and bulk $\delta^{13} \mathrm{C}$ and $\delta^{15} \mathrm{~N}$ values as well as between-bank differences in each species bulk $\delta^{13} \mathrm{C}$ and $\delta^{15} \mathrm{~N}$ values. Regression analysis was used to determine any relationship between carapace length and protein, lipid, and bulk $\delta^{13} \mathrm{C}$ and $\delta^{15} \mathrm{~N}$ values.

A linear mixed model, a generalization of the standard linear model (Wolfinger \& Chang 1995), was used to predict bank- and species-specific lipid, protein and amino acid $\delta^{15} \mathrm{~N}$ mean values and make statistical inferences about the data because of several sources of variation that existed. Variation originated from (1) replication from multiple injections of each sample during CSIA and repeated assays within each homogenate/lobster during protein analysis, and (2) unbalanced data from peak coelution in some of the amino acid injections and extreme outliers in some of the lipid and protein replicates. Models were fit in SAS (ver. 9.1, SAS Institute), which utilized a maximum likelihood approach.

\section{RESULTS}

\section{Effect of sex and size on biochemical analysis}

There was no effect of sex on protein, lipid, $\delta^{13} \mathrm{C}$ or $\delta^{15} \mathrm{~N}$ values (Table 1 ). Nor was there a carapace 
Table 1. Results ( $\mathrm{p}$-values) of $t$-tests and regression analysis examining the effect of sex and carapace length on protein, lipid and bulk $\delta^{13} \mathrm{C}$ and $\delta^{15} \mathrm{~N}$ values of spiny lobsters Panulirus marginatus and slipper lobsters Scyllarides squammosus

\begin{tabular}{|c|c|c|c|c|}
\hline & \multicolumn{2}{|c|}{ Sex } & \multicolumn{2}{|c|}{ Carapace length } \\
\hline & $\begin{array}{l}\text { Spiny } \\
\text { lobster }\end{array}$ & $\begin{array}{l}\text { Slipper } \\
\text { lobster }\end{array}$ & $\begin{array}{c}\text { Spiny } \\
\text { lobster }\end{array}$ & $\begin{array}{l}\text { Slipper } \\
\text { lobster }\end{array}$ \\
\hline Protein & 0.55 & 0.45 & 0.56 & 0.56 \\
\hline Lipid & 0.55 & 0.23 & 0.18 & 0.38 \\
\hline$\delta^{13} \mathrm{C}$ & 0.95 & 0.22 & 0.07 & 0.94 \\
\hline$\delta^{15} \mathrm{~N}$ & 0.51 & 0.77 & 0.47 & 0.39 \\
\hline
\end{tabular}

length effect on protein, lipid, $\delta^{13} \mathrm{C}$ or $\delta^{15} \mathrm{~N}$ values (Table 1). Therefore, no correction for sex or size was necessary for any of the biochemical techniques analyses.

\section{Proximate composition}

Spiny lobster protein levels were lower at Necker Island than at Maro Reef whereas slipper lobster protein levels were lower at Maro Reef than at Necker Island, but the differences between locations were not significant for either species $(\mathrm{p}=0.19, \mathrm{p}=0.27$ for spiny lobster and slipper lobster, respectively; Table 2). Spiny lobster and slipper lobster lipid levels were greater at Necker Island than at Maro Reef, but the differences between locations were not significant for either species ( $\mathrm{p}=0.07, \mathrm{p}=0.45$ for spiny lobster and slipper lobster, respectively; Table 2).

Table 2. Mean (SE) protein ( $\mathrm{mg} \mathrm{g}^{-1}$ tissue), lipid ( $\mathrm{mg} \mathrm{g}^{-1}$ tissue), bulk $\delta^{13} \mathrm{C}(\%)$ and $\delta^{15} \mathrm{~N}(\%)$, and amino acid $\delta^{15} \mathrm{~N}(\%)$ values of spiny lobster Panulirus marginatus and slipper lobster Scyllarides squammosus abdominal tissue at Necker Island and Maro Reef. Values were estimated using a linear mixed-effect model to account for the heterogeneity of the data set. Mean (SD) trophic level values were calculated using Eq. (2)

\begin{tabular}{|lrrrrr|}
\hline & \multicolumn{3}{c}{ Spiny lobster } & & \multicolumn{2}{c}{ Slipper lobster } \\
\cline { 2 - 3 } \cline { 5 - 6 } & Necker Island & Maro Reef & & Necker Island & Maro Reef \\
\hline Protein & $144.38(2.87)$ & $149.71(2.87)$ & & $130.39(2.02)$ & $127.22(1.98)$ \\
Lipid & $8.60(0.18)$ & $8.12(0.19)$ & & $7.05(0.37)$ & $6.66(0.35)$ \\
Bulk $\delta^{13} \mathrm{C}$ & $-14.1(0.46)$ & $-14.2(0.56)$ & & $-15.5(0.38)$ & $-15.1(0.36)$ \\
Bulk $\delta^{15} \mathrm{~N}$ & $7.1(0.51)$ & $6.7(0.48)$ & & $5.4(0.43)$ & $6.2(0.54)$ \\
Amino acid $\delta^{15} \mathrm{~N}$ & & & & & \\
Phenylalanine & $1.43(0.31)$ & $-0.49(0.27)$ & & $-1.45(0.23)$ & $1.27(0.25)$ \\
Glycine & $2.29(0.75)$ & $0.77(0.57)$ & & $-1.31(0.19)$ & $-2.06(0.21)$ \\
Alanine & $24.89(0.61)$ & $22.54(0.50)$ & $20.23(0.36)$ & $21.61(0.38)$ \\
Isoleucine & $14.79(0.73)$ & $14.73(0.55)$ & & $15.23(0.33)$ & $13.60(0.35)$ \\
Proline & $13.57(0.29)$ & $13.04(0.22)$ & & $8.97(0.21)$ & $10.36(0.23)$ \\
Aspartic acid & $16.32(0.48)$ & $15.12(0.37)$ & & $12.78(0.25)$ & $13.53(0.26)$ \\
Glutamic acid & $18.66(0.48)$ & $17.27(0.42)$ & & $16.34(0.31)$ & $16.68(0.33)$ \\
Trophic level & $2.82(0.04)$ & $2.89(0.04)$ & $2.89(0.03)$ & $2.58(0.03)$ \\
\hline
\end{tabular}

\section{Isotopic analysis}

$\delta^{13} \mathrm{C}$ values of bulk tissue

No significant difference was found in $\delta^{13} \mathrm{C}$ values between Necker Island and Maro Reef spiny lobsters ( $p=0.39)$; however, slipper lobsters at Maro Reef were significantly enriched in ${ }^{13} \mathrm{C}$ relative to slipper lobsters at Necker Island $(p<0.001)$ (Table 2). There were significant differences between spiny lobsters and slipper lobsters $\delta^{13} \mathrm{C}$ values within each bank (Necker Island $\mathrm{p}<0.001$, Maro Reef $\mathrm{p}<0.001$ ), with slipper lobsters having consistently lower values (Table 2).

$\delta^{15} \mathrm{~N}$ values of bulk tissue

Spiny lobsters at Necker Island were significantly enriched in ${ }^{15} \mathrm{~N}$ relative to spiny lobsters at Maro Reef ( $\mathrm{p}<0.001$ ) (Table 2, Fig. 2). The opposite pattern was found in slipper lobsters; Maro Reef lobsters were significantly enriched in ${ }^{15} \mathrm{~N}$ relative to slipper lobsters at Necker Island ( $p<0.001$; Table 2).

\section{Compound-specific isotopic analysis}

The $\delta^{15} \mathrm{~N}$ values of 7 amino acids varied widely (Table 2). Spiny lobster amino acid $\delta^{15} \mathrm{~N}$ values ranged from -0.49 to $24.89 \%$ and slipper lobster amino acid $\delta^{15} \mathrm{~N}$ values from -2.06 to $21.61 \%$. Phenylalanine was identified as the primary 'source' amino acid because its $\delta^{15} \mathrm{~N}$ value indicated very little enrichment of ${ }^{15} \mathrm{~N}$; therefore, we assume that it reflects the $\delta^{15} \mathrm{~N}$ value at the base of the lobsters' food web. Glycine, which can be used as a source amino acid (McClelland \& Montoya 2002, Popp et al. 2007), also had relatively low $\delta^{15} \mathrm{~N}$ values but was not designated as the primary source amino acid in this case because of large variability in $\delta^{15} \mathrm{~N}$ values, particularly in spiny lobster. Large variation in $\delta^{15} \mathrm{~N}$ values of glycine is not atypical (McCarthy et al. 2007, Chikaraishi et al. 2007, 2009). The amino acids most enriched in ${ }^{15} \mathrm{~N}$ relative to the source amino acids (alanine, isoleucine, proline, aspartic acid and glutamic acid) were considered 'trophic' amino acids because of the expected enrichment that occurred 
during metabolic processes. These designations as source and trophic amino acids are consistent with those of McClelland \& Montoya (2002), Popp et al. (2007) and Chikaraishi et al. (2007, 2009). To account for the $\delta^{15} \mathrm{~N}$ value at the base of the food web, the identified trophic amino acids were normalized according to their difference from phenylalanine. Glutamic acid, although depleted in ${ }^{15} \mathrm{~N}$ relative to alanine, was selected as the primary trophic amino acid because variability in the $\delta^{15} \mathrm{~N}$ value of glutamic acid was consistently lower than that of alanine.

Spiny lobster phenylalanine $\delta^{15} \mathrm{~N}$ values were significantly different between Necker Island and Maro Reef ( $p<0.001$; Table 2, Fig. 2). There was inconclusive evidence of a difference in glycine $(p=0.05)$, and the values at Maro Reef were in the other direction from that of phenylalanine (Table 2, Fig. 2). After accounting for the $\delta^{15} \mathrm{~N}$ value at the base of the food web (i.e. normalizing according to their differences from phenylalanine), there were no significant differences in glutamic acid $(p=0.23)$ or alanine $(p=0.49)$ between Necker Island and Maro Reef spiny lobsters, there was inconclusive evidence of a difference in aspartic acid $(\mathrm{p}=0.05)$, and there were significant differences in isoleucine $(\mathrm{p}<0.001)$ and proline $(\mathrm{p}=$ 0.01; Fig. 2). There was no significant difference in spiny lobster trophic position between banks $(\mathrm{p}=$ 0.23 ) when phenylalanine represented the source amino acid and glutamic acid represented the trophic amino acid (Table 2, Fig. 2).

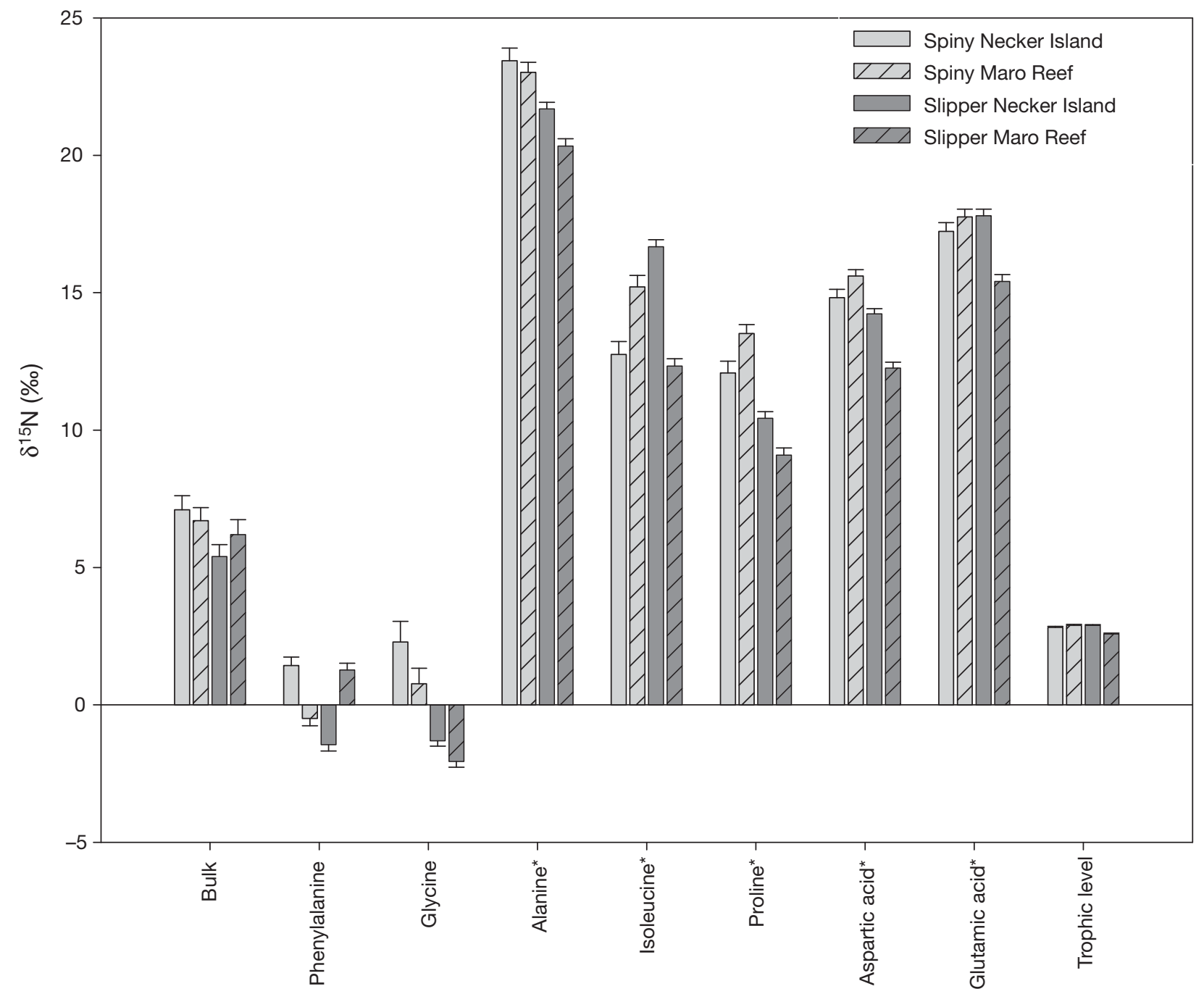

Fig. 2. Necker Island and Maro Reef spiny lobster Panulirus marginatus and slipper lobster Scyllarides squammosus bulk tissue $\delta^{15} \mathrm{~N}$, individual amino acid stable isotope values and trophic position. Values (means + SE) were estimated using a linear mixed-effects model to account for the heterogeneity of the data set. Asterisks indicate trophic amino acids normalized according to their difference from phenylalanine $\left(\delta^{15} \mathrm{~N}_{\mathrm{x}}=\delta^{15} \mathrm{~N}_{\mathrm{x}}-\delta^{15} \mathrm{~N}_{\mathrm{Phe}} \%\right.$ ) 
There was also a significant difference between Necker Island and Maro Reef $\delta^{15} \mathrm{~N}$ values at the base of the slipper lobster food web, represented by phenylalanine $(\mathrm{p}<0.001 ;$ Table 2$)$. There was also a significant difference in glycine $(\mathrm{p}<0.001)$ and, similar to spiny lobsters, the Maro Reef values were in the opposite direction of those of phenylalanine (Table 2). All of the trophic amino acids, normalized to phenylalanine, showed significant between-bank differences $(\mathrm{p}<0.001)$, with Maro Reef slipper lobsters consistently exhibiting lower $\delta^{15} \mathrm{~N}$ values than Necker Island slipper lobsters (Fig. 2). Consequently, the trophic position of Maro Reef slipper lobsters was significantly lower than that at Necker Island ( $\mathrm{p}<$ 0.001; Table 2, Fig. 2).

Significant differences in phenylalanine $\delta^{15} \mathrm{~N}$ values were also found between spiny lobsters and slipper lobsters within each bank (Necker Island $\mathrm{p}=$ 0.001 , Maro Reef $p=0.001$; Table 2).

\section{DISCUSSION}

\section{Nutritional stress and starvation}

Indicators of nutritional stress and starvation did not definitively identify diet as the primary driver of growth variability. In the case of proximate composition analysis, this was not necessarily unexpected because the hepatopancreas, the site of major storage reserves in decapod crustaceans (Dall 1981, Johnston et al. 1998), is a more sensitive indicator of crustacean nutritional stress than abdominal tissue (Trendall \& Prescott 1989, Cockcroft 1997). However, proximate composition analysis of abdominal tissue suggested that dietary differences between banks affected growth of NWHI spiny lobsters and slipper lobsters because mean protein levels, although not statistically significant, matched the spatial growth variability. Within each species, protein levels were lower at the banks with slower growth.

Bulk tissue isotopic analysis indicated enrichment of ${ }^{15} \mathrm{~N}$ in lobsters at the banks with slower growth, Necker Island for spiny lobsters and Maro Reef for slipper lobsters. Typically, a greater $\delta^{15} \mathrm{~N}$ value suggests a higher trophic level. In this case, because the higher $\delta^{15} \mathrm{~N}$ values occurred at the locations where lobsters were growing more slowly, another plausible interpretation would be starvation. Starving individuals catabolize their tissues, which results in progressive ${ }^{15} \mathrm{~N}$ enrichment and thus increased $\delta^{15} \mathrm{~N}$ values (Hobson et al. 1993, Adams \& Sterner 2000). However, the lack of isotopic information of the base of the lobsters' food web precludes definitive confirmation of this interpretation.

CSIA revealed that any interpretations of the NWHI lobster bulk isotopic data without accounting for the base of the food web are spurious. Necker Island spiny lobsters and Maro Reef slipper lobsters were significantly enriched in bulk tissue ${ }^{15} \mathrm{~N}$ relative to their spatial counterparts, but the phenylalanine $\delta^{15} \mathrm{~N}$ values from the CSIA indicated that those differences were not solely a function of trophic level differences or starvation because of differences in the $\delta^{15} \mathrm{~N}$ values at the base of each species' food web. This finding demonstrates the power of CSIA and the danger of using only consumer bulk tissue isotopic data without accounting for variation in the nitrogen isotopic composition at the base of the food web (McClelland \& Montoya 2002).

\section{Trophic position}

The CSIA-based assessment of fractionation trophic position indicates that there was no difference in the trophic positions of Necker Island and Maro Reef spiny lobsters. There were, however, significant differences in the $\delta^{15} \mathrm{~N}$ values between Necker Island and Maro Reef slipper lobster trophic amino acids once the base of the food web was accounted for, as well as a difference in the calculated trophic position. The amino acid $\delta^{15} \mathrm{~N}$ values and the trophic position indicated that Maro Reef slipper lobsters were feeding at a lower trophic level than Necker Island slipper lobsters, a clear indication of differences in diet.

\section{Diet and growth}

The NWHI is a complex and dynamic ecosystem that is poorly understood. Necker Island is a basalt island with lower coral and fish species richness than Maro Reef, an open atoll (Friedlander et al. 2009). The species composition and abundances of lobster prey items may also vary spatially among banks because of different recruitment dynamics, habitat availability, and other biotic and abiotic factors. An examination of the bycatch (nontarget species including hermit crabs, calappid crabs, portunid crabs, eels and fish) captured during fishery-independent lobster trapping operations found differences between Necker Island and Maro Reef in several diversity indices, including Simpson's diversity index and measure of evenness, and Margalef's diversity index (Moffitt et al. 2006). Although not originally intended to be a comparison be- 
tween locations, it is, nonetheless, a useful indication of spatial differences in the species diversity in the exact habitat utilized by these lobsters.

Spatial variability in the abundance or diversity of preferred prey items appears to be responsible for the spatial variability in NWHI spiny lobster and slipper lobster growth. Lobsters are omnivorous (Phillips et al. 1980, Nelson et al. 2006), with a preference for highquality (i.e. high nutrient content) species such as gastropods, bivalves, chitons and crustaceans (Childress \& Jury 2006, Johnston 2007). Although they consume plant material, a diet of coralline and fleshy algae does not provide the energy necessary for lobster basal metabolism, whereas mollusks provide several times the energetic requirements (Edgar 1990).

Prey availability and diversity drives growth dynamics in 2 other lobster species (Edgar 1990, Mayfield et al. 2000), although the 2 species exhibited different behavioral responses to food shortages. There were large differences in the benthic species composition between fast and slow growth areas of South African Jasus lalandii. The biomass of edible (nutritionally beneficial) components of the benthos was nearly twice as high at the fast growth areas and the preferred prey items, black mussels Choromytilus meridionalis and ribbed mussels Aulacomya ater, were rare or absent in the slow growth area (Mayfield et al. 2000). Yet there were no differences in the $J$. lalandii diet between the 2 areas, suggesting that $J$. lalandii actively foraged for the specific prey items at the energetic expense of growth. In contrast, the relationship between growth and diet in Western Australian Panulirus cygnus reflected the benthos (Edgar 1990). In areas with comparatively lower recruitment of the trochid mollusk Cantharidus lepidus, lobsters ate more epiphytic coralline algae and grew slower. This indicates that slower-growing individuals supplemented their diet with more available yet nutritionally poor prey items. Spiny lobsters at Necker Island grew slower than spiny lobsters at Maro Reef (O'Malley 2009), yet, according to CSIA, they fed at the same trophic level. If the preferred prey items were depauperate at Necker Island relative to Maro Reef, then spiny lobsters at Necker Island allocated more energy foraging at the energetic expense of growth, a strategy similar to that of J. lalandii. Slipper lobsters at Maro Reef grew slower than slipper lobsters at Necker Island (O'Malley 2011) and, according to CSIA, fed at a lower trophic position. If nutritionally high prey items were limited at Maro Reef relative to Necker Island, then Maro Reef slipper lobsters supplemented their diet with more readily available, yet nutritionally poor food items, a strategy similar to that of $P$. cygnus. Therefore, prey availability rather than diet per se appears to be driving the spatial variability in NWHI spiny lobster and slipper lobster growth.

These 2 NWHI benthic omnivores, despite similar shortages in their respective preferred prey items, approached the situation in a manner that may reflect differences in morphology and behavior. Although both spiny lobsters and slipper lobsters are capable of flight via tail flipping, spiny lobsters possess antipredator mechanisms such as weaponry (Kanciruk 1980, Barshaw et al. 2003) and stridulation, the rasping sound from the stridulatory organ (Childress \& Jury 2006, Bouwma \& Herrnkind 2009). The robust and spiny antenna of spiny lobsters combined with stridulation provide an effective defense mechanism when confronted by a predator outside shelter (Barshaw et al. 2003, Childress \& Jury 2006), thereby allowing spiny lobsters to forage openly (i.e. travel across large expanses of sand) to locate preferred prey items. Slipper lobsters lack morphological weapons and are dependent upon predator-avoidance mechanisms such as strong amour, crypsis, immobility and a slow lifestyle for survival (Barshaw \& Spanier 1994, Barshaw et al. 2003). Because slipper lobsters do not possess active defense mechanisms, they are restricted in their ability to forage for their preferred prey items. The lack of a nutritionally high food supply at the banks, along with slower growth and top-down pressure within this apex-predatordominated system (Friedlander \& DeMartini 2002), to which each species responds differently, are likely driving the growth variability in NWHI lobsters.

\section{CONCLUSIONS}

Biochemical composition, as revealed by CSIA of proteinaceous amino acids, provides evidence that prey availability is the driving mechanism of the spatial variability in growth of NWHI spiny lobsters and slipper lobsters. The specific morphology and behavior of these species dictated how each coped with limited food. Based on these data and previous feeding studies of lobsters, we propose that NWHI spiny lobsters are foragers fixated on acquiring a select prey item, or collection of prey, and their morphology and behavior enables them to actively pursue that item. In contrast, the morphology and behavior of NWHI slipper lobsters are not conducive to open active foraging, hence they are limited to the most readily available prey items. The results of this study support a metapopulation approach to research and 
management not only of lobsters in the NWHI, but any species whose life history traits are impacted by variable prey abundance.

Acknowledgements. We thank J. Friedman, K. Arthur, G. DiNardo, H. Lee, R. Humphreys and K. Piner for assistance in the multitude of techniques used in this study. Helpful comments were provided in reviews by B. Bowen, W. Walsh, Y. Cherel and 3 anonymous reviewers. Financial support was provided by National Oceanic and Atmospheric Administration Cooperative Research Program, The Charles H. and Margaret B. Edmondson Research Grant (J.M.O.), and National Science Foundation Grants OCE06-23678 (R.J.T) and OCE-1041329 (B.N.P. and J.C.D.). This is HIMB Contribution Number 1474 and SOEST contribution number 8516. Northwestern Hawaiian Islands activity was conducted under permit numbers NWHICRER-2006-003, PMNM2007-023 and PMNM-2008-044.

\section{LITERATURE CITED}

Adams TS, Sterner RW (2000) The effect of dietary nitrogen content on trophic level ${ }^{15} \mathrm{~N}$ enrichment. Limnol Oceanogr 45:601-607

Barshaw DE, Spanier E (1994) Anti-predator behaviors of the Mediterranean slipper lobster, Scyllarides latus. Bull Mar Sci 55:375-382

Barshaw DE, Lavalli KL, Spanier E (2003) Offense versus defense: responses of three morphological types of lobsters to predation. Mar Ecol Prog Ser 256:171-182

Bligh EG, Dyer WJ (1959) A rapid method of total lipid extraction and purification. Can J Biochem Physiol 37: 911-917

Bouwma PE, Herrnkind WF (2009) Sound production in Caribbean spiny lobster Panulirus argus and its role in escape during predatory attack by Octopus briareus. NZ J Mar Freshw Res 43:3-13

- Cabana G, Rasmussen JB (1996) Comparison of aquatic food chains using nitrogen isotopes. Proc Natl Acad Sci USA 93:10844-10847

Chang ES, O'Connor JD (1983) Metabolism and transport of carbohydrates and lipids. In: Mantel LH (ed) The biology of Crustacea, Vol 5. Academic Press, New York, NY, p 263-287

Chikaraishi Y, Kashiyama Y, Ogawa NO, Kitazato H, Ohkouchi N (2007) Metabolic control of nitrogen isotope composition of amino acids in macroalgae and gastropods: implications for aquatic food web studies. Mar Ecol Prog Ser 342:85-90

Chikaraishi Y, Ogawa NO, Takano Y, Suga H and others (2009) Determination of aquatic food-web structure based on compound-specific nitrogen isotopic composition of amino acids. Limnol Oceanogr Methods 7:740-750

Childress MJ, Jury SH (2006) Behavior. In: Phillips BF (ed) Lobsters: biology, management, aquaculture, and fisheries. Blackwell Scientific Publications, Oxford, p 78-112

Chittleborough RG (1975) Environmental factors affecting growth and survival of juvenile western rock lobsters Panulirus longipes (Milne-Edwards). Mar Freshw Res 26: 177-196

Claybrook DL (1983) Nitrogen metabolism. In: Mantel LH (ed) The biology of Crustacea, Vol 5. Academic Press, New York, p 163-213

> Cockcroft AC (1997) Biochemical composition as a growth predictor in male west-coast rock lobster (Jasus lalandii). Mar Freshw Res 48:845-856

Conklin DE (1980) Nutrition. In: Cobb JS, Phillips BF (eds) The biology and management of lobsters, Vol 1. Academic Press, New York, NY, p 277-300

Conover DO, Munch SB (2002) Sustaining fisheries yields over evolutionary time scales. Science 297:94-96

Dale JJ, Wallsgrove NJ, Popp BN, Holland KN (2011) Nursery habitat use and foraging ecology of the brown stingray Dasyatis lata determined from stomach contents, bulk and amino acid stable isotopes. Mar Ecol Prog Ser 433:221-236

Dall W (1974) Indices of nutritional state in the western rock lobster, Panulirus longipes (Milne Edwards). I. Blood and tissue constituents and water content. J Exp Mar Biol Ecol 16:167-180

Dall W (1981) Lipid absorption and utilization in the Norwegian lobster, Nephrops morvegicus (L.). J Exp Mar Biol Ecol 50:33-45

Dall W, Moriarty DJW (1983) Functional aspects of nutrition and digestion. In: Mantel LH (ed) The biology of Crustacea, Vol 5. Academic Press, New York, NY, p 215-261

- Delestang S, Caputi N, Melville-Smith R (2009) Using finescale catch predictions to examine spatial variation in growth and catchability of Panulirus cygnus along the west coast of Australia. NZ J Mar Freshw Res 43:443-455

> DeNiro MJ, Epstein S (1978) Influence of diet on the distribution of carbon isotopes in animals. Geochim Cosmochim Acta 42:495-506

DeNiro MJ, Epstein S (1981) Influence of diet on the distribution of nitrogen isotopes in animals. Geochim Cosmochim Acta 45:341-351

> Drazen JC (2002) A seasonal analysis of the nutritional condition of deep-sea macrourid fishes in the north-east Pacific. J Fish Biol 60:1280-1295

> Edgar GJ (1990) Predator-prey interactions in seagrass beds. I. The influence of macrofaunal abundance and sizestructure on the diet and growth of the western rock lobster Panulirus cygnus George. J Exp Mar Biol Ecol 139: $1-22$

Fogarty MJ (1995) Populations, fisheries, and management. In: Factor JR (ed) Biology of the lobster Homarus americanus. Academic Press, New York, NY, p 111-137

Friedlander AM, DeMartini EE (2002) Contrasts in density, size, and biomass of reef fishes between the northwestern and the main Hawaiian islands: the effects of fishing down apex predators. Mar Ecol Prog Ser 230:253-264

Friedlander A, Keller K, Wedding L, Clarke A, Monaco M (2009) A marine biogeographic assessment of the Northwestern Hawaiian Islands. NOAA Tech Memo NOS NCCOS 84, Silver Springs, MD

Gelwicks JT, Hayes JM (1990) Carbon-isotope analysis of dissolved acetate. Anal Chem 62:535-539

> Hannides CS, Popp BN, Landry MR, Graham BS (2009) Quantification of zooplankton trophic position in the North Pacific Subtropical Gyre using stable nitrogen isotopes. Limnol Oceanogr 54:50-61

> Hobson KA, Alisauskas RT, Clark RG (1993) Stable-nitrogen isotope enrichment in avian tissues due to fasting and nutritional stress: implications for isotopic analyses of diet. Condor 95:388-394

Johnston D (2007) Feeding morphology and digestive system of slipper lobsters. In: Lavalli KL, Spanier E (eds) The biology and fisheries of the slipper lobster. CRC Press, Boca Raton, FL, p 111-132

Johnston DJ, Alexander CG, Yellowhees D (1998) Epithelial cytology and function in the digestive gland of Thenus 
orientalis (Decapoda, Scyllaridae). J Crustac Biol 18: 271-278

Kanciruk P (1980) Ecology of juvenile and adult Palinuridae (spiny lobsters). In: Cobb JS, Phillips BF (eds) The biology and management of lobsters, Vol 2. Academic Press, New York, NY, p 59-96

> Lorrain A, Graham B, Ménard F, Popp B, Bouillon S, van Breugel P, Cherel Y (2009) Nitrogen and carbon isotope values of individual amino acids: a tool to study foraging ecology of penguins in the Southern Ocean. Mar Ecol Prog Ser 391:293-306

> Lourey MJ, Trull TW, Sigman DM (2003) Sensitivity of $\delta^{15} \mathrm{~N}$ of nitrate, surface suspended and deep sinking particulate nitrogen to seasonal nitrate depletion in the Southern Ocean. Global Biogeochem Cycles 17:1081 doi: 10.1029/2002GB001973

Lyle WG, MacDonald CD (1983) Molt stage determination in the Hawaiian spiny lobster, Panulirus marginatus. J Crustac Biol 3:208-216

Marsh JB, Weinstein DB (1966) Simple charring method for determination of lipids. J Lipid Res 7:574-576

Mayfield S, Branch GM, Cockcroft AC (2000) Relationship among diet, growth rate and food availability for the South African rock lobster, Jasus lalandii (Decapoda, Palinuridea). Crustaceana 73:815-834

McCarthy MD, Benner R, Lee C, Fogel ML (2007) Amino acid nitrogen isotopic fractionation patterns as indicators of heterotrophy in plankton, particulate, and dissolved organic matter. Geochim Cosmochim Acta 71:4727-4744

McClelland JW, Montoya JP (2002) Trophic relationships and the nitrogen isotopic composition of amino acids in phytoplankton. Ecology 83:2173-2180

McGarvey R, Ferguson GJ, Prescott JH (1999) Spatial variation in mean growth rates at size of southern rock lobster, Jasus edwardsii, in South Australian waters. Mar Freshw Res 50:333-342

Mente E (2003) Nutrition, physiology and metabolism of crustaceans. Science Publishers, Enfield, NH

- Minagawa M, Wada E (1984) Stepwise enrichment of ${ }^{15} \mathrm{~N}$ along food chains: further evidence and the relation between $\delta^{15} \mathrm{~N}$ and animal age. Geochim Cosmochim Acta 48:1135-1140

Moffitt RB, Johnson J, DiNardo G (2006) Spatiotemporal analysis of lobster trap catches: impacts of trap fishing on community structure. Atoll Res Bull 543:217-236

Nelson MN, Bruce MP, Nichols PD, Jeffs AG, Phleger C (2006) Nutrition of wild and cultured lobsters. In: Phillips BF (ed) Lobsters: biology, management, aquaculture, and fisheries. Blackwell Scientific Publications, Oxford, p 205-230

O'Malley JM (2009) Spatial and temporal variability in growth of Hawaiian spiny lobsters in the Northwestern Hawaiian Islands. Mar Coast Fish 1:325-342

O'Malley JM (2011) Spatiotemporal variation in the population ecology of scaly slipper lobsters, Scyllarides squammosus in the Northwestern Hawaiian Islands. Mar Biol 158:1887-1901

> Peterson BJ, Fry B (1987) Stable isotope in ecosystem studies. Annu Rev Ecol Syst 18:293-320

Phillips BF, Cobb JS, George RW (1980) General biology. In: Cobb JS, Phillips BF (eds) The biology and management of lobsters, Vol 1. Academic Press, New York, NY, p 1-82

Pollock DE (1991) Spiny lobster at Tristan da Cunha, South Atlantic: inter-island variations in growth and population structure. S Afr J Mar Sci 10:1-12

Popp BN, Graham BS, Olson RJ, Hannides CCS and others (2007) Insight into the trophic ecology of yellowfin tuna,
Thunnus albacares, from compound-specific nitrogen isotope analysis of proteinaceous amino acids. In: Dawson TE, Siegwolf RTW (eds) Stable isotopes as indicators of ecological change. Academic Press, New York, NY, p 173-190

> Post DM (2002) Using stable isotopes to estimate trophic position: models, methods and assumptions. Ecology 83: 703-718

> Rindorf A, Jensen H, Schrum C (2008) Growth, temperature, and density relationships of North Sea cod (Gadus morhua). Can J Fish Aquat Sci 65:456-470

Sarà G (2007) Sedimentary and particulate organic matter: mixed sources for cockle Cerastoderma glaucum in a shallow pond, Western Mediterranean. Aquat Living Resour 20:271-277

Seeb LW, Seeb JE, Polovina JJ (1990) Genetic variation in highly exploited spiny lobster Panulirus marginatus populations from the Hawaiian Archipelago. Fish Bull 88: 713-718

Shaklee JB, Samollow PB (1984) Genetic variation and population structure in a spiny lobster, Panulirus marginatus in the Hawaiian archipelago. Fish Bull 82:693-702

Smith PK, Krohn RI, Hermanson GT, Mallia AK and others (1985) Measurement of protein using bicinchoninic acid. Anal Biochem 150:76-85

Toonen RJ, Andrews KR, Baums IB, Bird CE and others (2011) Defining boundaries for ecosystem-based management: a multispecies case study of marine connectivity across the Hawaiian Archipelago. J Mar Biol 2011: 460173

Torres JJ, Donnelly J, Hopkins TL, Lancraft TM, Aarset AV, Ainley DG (1994) Proximate composition and overwintering strategies of Antarctic micronektonic Crustacea. Mar Ecol Prog Ser 113:221-232

Trendall JT, Prescott J (1989) Severe physiological stress associated with the annual breeding emigration of Panulirus ornatus in the Torres Strait. Mar Ecol Prog Ser 58: 29-39

Uchida RN, Uchiyama JN, Tagami DT, Shiota PM (1980) Biology, distribution, and estimates of apparent abundance of the spiny lobster, Panulirus marginatus (Quoy and Gaimard), in waters of the Northwestern Hawaiian Islands. Part 2. Size distribution, legal to sublegal ratio, sex ratio, reproductive cycle, and morphometric characteristics. In: Grigg RW, Pfund RT (eds) Proc Symp Status of Res Invest NWHI. Misc Rep UNIHI-SEAGRANT-MR80-04. University of Hawaii Sea Grant College Program, Honolulu, HI, p 131-142

> Ueda K, Morgan SL, Fox A, Gilbart J, Sonesson A, Larsson L, Odham G (1989) D-alanine as a chemical marker for the determination of streptococcal cell wall levels in mammalian tissues by gas chromatography/negative ion chemical ionization mass spectrometry. Anal Chem 61: 265-270

Wahle RA, Fogarty MJ (2006) Growth and development: understanding and modeling growth variability in lobsters. In: Phillips BF (ed) Lobsters: biology, management, aquaculture, and fisheries. Blackwell Scientific Publications, Oxford, p 1-44

Wolfinger RD, Chang M (1995) Comparing the SAS GLM and MIXED procedures for repeated measures. Proceedings of the 20th SAS Users Group Conference, SAS Institute, Cary, NC, p 1172-1182

Yokoyama H, Tamaki A, Harada K, Shimoda K, Koyama K, Ishihi Y (2005) Variability of diet-tissue isotopic fractionation in estuarine macrobenthos. Mar Ecol Prog Ser 296: $115-128$ 